\section{DNAAneuploidy in Malignant Salivary Gland Neoplasms is Independent of USP44 Protein Expression}

Vanessa Fátima Bernardes ${ }^{1}$, Edward W Odell ${ }^{2}$, Ricardo Santiago Gomez ${ }^{3}$ Carolina Cavalieri Gomes ${ }^{1}$

\author{
'Department of Pathology, \\ Biological Sciences Institute, UFMG \\ - Universidade Federal de Minas \\ Gerais, Belo Horizonte, MG, Brazil \\ ${ }^{2}$ Division of Salivary and Mucosal \\ Research, Oral Pathology, \\ King's College London Dental \\ Institute, London, UK \\ ${ }^{3}$ Department of Oral Pathology and \\ Medicine, Dental School, UFMG \\ - Universidade Federal de Minas \\ Gerais, Belo Horizonte, MG, Brazil
}

Correspondence: Vanessa F. Bernardes, Av. Presidente Antônio Carlos 6627, Pampulha, 31270-901 Belo Horizonte, MG, Brasil. Tel: +55-31-3409-2477 e-mail: bernardesvf@icb.ufmg.br

Key Words: ubiquitin specific protease, mucoepidermoid carcinoma, adenoid cystic carcinoma, polymorphous low grade adenocarcinoma, carcinoma ex-pleomorphic adenoma, epithelial-myoepithelial carcinoma.

\section{Introduction}

USP44 is located at $12 \mathrm{q} 22$ and encodes a 712 amino acid protein, USP44, a member of the ubiquitin-specific protease (USP) family that shows deubiquitylating activity $(1,2)$. USP44 is an important regulator of the mitotic checkpoint by regulation of centrosome separation, positioning and mitotic spindle geometry (3-5).

In humans, only tests showed detectable USP44 RNA amount by Northern Blot analysis and the mRNA was not detected in other organs such as ovary, colon, liver, lung, brain and kidney (1), but USP44 mRNA expression levels are reduced in human lung adenocarcinomas and the reduced level correlates with poor prognosis (5). The role of USP44 is better defined in mouse, where USP44 mRNA was detected by in situ hybridization and RT-PCR in all organs (2). USP44homozygous-null mice are born healthy at Mendelian allele frequencies, suggesting USP44 is not essential for cell viability or mouse embryogenesis (5). However, mice lacking USP44 are highly prone to spontaneous tumor formation and USP44 loss causes chromosome mis-segregation, aneuploidy and tumorigenesis in vivo (5).

The DNA ploidy status has been previously investigated in salivary gland tumors and showed that only malignant tumors are aneuploid (6-8). However, the frequency of aneuploidy in this group of lesions is lower than in other solid tumors (9). In addition, the molecular basis of chromosomal instability and aneuploidy in salivary neoplasms is not clear. On the basis of USP44 role in the mitotic checkpoint, this study tested whether USP44 protein expression differed between aneuploid and diploid human malignant salivary gland neoplasms.

\section{Material and Methods Human Tumor Samples}

Twenty-eight salivary gland cancer samples were included in the study, comprising 7 samples of polymorphous low-grade adenocarcinoma (PLGA), 5 samples of adenoid cystic carcinoma (ACC), 4 samples of epithelial-myoepithelial carcinoma (EMC), 4 high-grade and 2 intermediate-grade mucoepidermoid carcinomas (MEC) and 6 carcinomas ex-pleomorphic adenoma ( $\mathrm{Ca}$ ex PA). The study was approved by the UFMG Ethics Committee (Protocol 152/07). Details of this cohort of samples and ploidy analysis results have been previously published $(8,10)$. Considering the evidence of better outcome of tumors reported as the $4 \mathrm{~cm}$ rule, the samples were grouped in two categories ( $\leq 4 \mathrm{~cm}$ or $>4 \mathrm{~cm}$ ). According to this "rule" the extension of the neoplasm at presentation is a strong predictor of tumor behavior (11). The association between tumor DNA ploidy and tumour size was interrogated by chi-square or Fisher's exact test, when appropriate. $p$ values $<0.05$ were considered statistically significant.

\section{DNA Ploidy Analysis and Immunohistochemistry (IHC)}

Ploidy analysis was performed as previously reported $(8,10)$. Details of this cohort of samples and ploidy analysis results have been previously published $(8,10)$. 
Briefly, the tissue sections were digested by protease XXIV (Sigma-Aldrich Co. Ltd., Poole, Dorset, UK) and prepared into a monolayer by cytospining. Nuclei were stained by Feulgen and Periodic-acid-Schiff (PAS), with a minimum of 300 nuclei of tumor cells being assessed and lymphocytes used as internal diploid controls. The analysis was performed using a cytometric image analysis system (Fairfield Imaging Ltd, Medical Solutions, Nottingham, UK). Immunohistochemistry was carried out following standard protocols using USP44 antibody (HPA026543, SigmaAldrich, Inc., St. Louis, MO, USA) at 1:50. The immunogen for this antibody corresponds to aminos acid 104-249 (Uniprot 09H0E7). Tubulin antibody (clone DM1A, 1:50, Santa Cruz Biotechnology, Santa Cruz, TX, USA) was used to ensure that negative areas were immunoreactive and not false-negative due to fixation or other tissue preservation variables. Deparaffinization, hydration and antigen retrieval were perfomed using Trylogy solution (Cell Marque, Rocklin, CA, USA). Endogenous peroxidase was blocked using 10\% hydrogen peroxide. Reactions were visualized by a polymerbased system (EnVision, Dako Corporation, Carpinteria, CA, USA) followed by diaminobenzidine as chromogen. Positive controls consisted of normal oral mucosa and negative reaction control was carried out by omitting the primary antibody. Immunohistochemical positivity was evaluated in whole tumor sections and the percentage of positivity was graded as follows: $0-25 \%$; 25-50\%; 50-75\%; and >75\%, regardless of intensity (12). Tumor sections were evaluated independently by two pathologists (VFB and CCG) and they revised together the cases whose results were inconsistent.

\section{Results}

The clinicopathological, DNA ploidy status and immunohistochemical data of the samples are in Table 1. There was no significant association between DNA ploidy and tumor size after performing chi-square or Fisher's exact test $(p>0.05)$. The cytoplasm of the tumor cells was ubiquitously positive for USP44, and tubulin positive areas confirmed the viability of the tissue specimens. A high percentage of USP44 positivity cells was detected in most samples. Seventeen out of 19 diploid and all the aneuploid samples $(n=9)$ showed more than $50 \%$ of USP44 positive tumor cells. Representative examples of the protein expression patterns in different tumors such as EMC, MEC and PLGA are represented in Figures $1 \mathrm{~A}, 1 \mathrm{~B}$ and $1 \mathrm{C}$ respectively. Interestingly, there was a smaller percentage of USP44 positivity in tumor cells in ACC samples compared to other tumor groups. The EMCs showed preferential expression in the cells with epithelial differentiation compared to the myo-epithelial cells. Immunohistochemical detection of USP44 in normal salivary glands associated with the tumors $(n=22)$ showed positive staining mainly in the ductal cells, whereas serous acini showed negative or weak staining. This result is consistent with the data provided by the Human Protein Atlas (In: http://www. proteinatlas.org/ENSG00000136014/tissue/salivary+gland) and the terminal differentiation of acinar cells.

\section{Discussion}

There is a suggestion that USP44 is a critical regulator of spindle checkpoint by the equilibrium of ubiquitination and deubiquitination (3). Zhang et al. found increased levels of aneuploidy in the spleens of USP44-null animals and these animals exhibited increased rates of tumorigenesis (5). However, one cannot assume that the aneuploidy induced by loss of USP44 leads to tumor formation (13). Malfunction or absence of USP44 might only be one factor in development of chromosomal instability (13). There was no clear association between USP44 expression and DNA ploidy status of the malignant salivary gland tumours, suggesting that aneuploidy is independent of the expression levels of this protein. One cannot exclude the possibility that the detected protein is altered by mutations. However, this possibility is small as this gene exhibits a
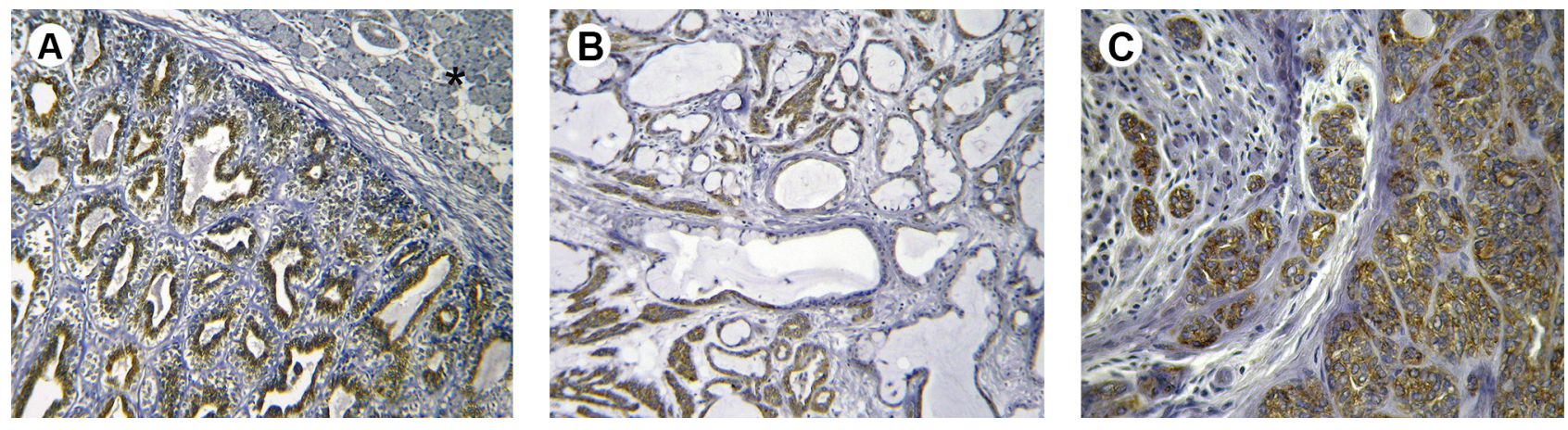

Figure 1. Immunohistochemical expression of USP44 in salivary gland tumors. Epithelial-myoepithelial carcinoma (a), mucoepidermoid carcinoma (b) and polymorphous low-grade adenocarcinoma (c) exhibiting protein expression in the majority of neoplastic cells. $\left({ }^{*}\right)$ normal salivary glands adjacent to tumor showing negative protein expression. Original magnification 100× (A,B) and 400× (C). 
Table 1. Clinical, histopathological data, ploidy and immunohistochemical expression results of USP44 in the malignant salivary gland tumors included in the study

\begin{tabular}{|c|c|c|c|c|c|c|}
\hline Diagnosis and sample number & Age & Sex & Site & $\begin{array}{c}\text { Tumor size } \\
\text { (in the largest dimension) }\end{array}$ & DNA ploidy & $\begin{array}{c}\text { USP44 } \\
\text { IHC positivity (\%) }\end{array}$ \\
\hline \multicolumn{7}{|l|}{$\begin{array}{l}\text { Polymorphous low grade } \\
\text { adenocarcinoma }\end{array}$} \\
\hline$\# 1$ & 66 & $\mathrm{~F}$ & Palate & $\leq 4 \mathrm{~cm}$ & Diploid & $>75$ \\
\hline \#2 & 70 & $\mathrm{~F}$ & Palate & $\leq 4 \mathrm{~cm}$ & Diploid & $>75$ \\
\hline \#3 & 39 & M & Palate & $\leq 4 \mathrm{~cm}$ & Diploid & $>75$ \\
\hline \#4 & 44 & M & Lip & $\leq 4 \mathrm{~cm}$ & Diploid & $>75$ \\
\hline \#5 & 73 & $\mathrm{~F}$ & Palate & $\leq 4 \mathrm{~cm}$ & Aneuploid & $>75$ \\
\hline \#6 & 67 & M & Palate & $\leq 4 \mathrm{~cm}$ & Diploid & $>75$ \\
\hline$\# 7$ & 50 & M & Palate & $\leq 4 \mathrm{~cm}$ & Aneuploid & $>75$ \\
\hline \multicolumn{7}{|l|}{ Adenoid cystic carcinoma } \\
\hline$\# 8$ & 75 & M & $\begin{array}{l}\text { Minor gland } \\
\text { floor mouth }\end{array}$ & $>4 \mathrm{~cm}$ & Diploid & $50-75$ \\
\hline \#9 & 66 & $\mathrm{~F}$ & Submandibular & $\leq 4 \mathrm{~cm}$ & Diploid & $0-25$ \\
\hline$\# 10$ & 55 & $\mathrm{~F}$ & Submandibular & $>4 \mathrm{~cm}$ & Diploid & $0-25$ \\
\hline \#11 & 49 & M & Parotid & $\leq 4 \mathrm{~cm}$ & Diploid & $50-75$ \\
\hline \#12 & 50 & $\mathrm{~F}$ & Palate & $>4 \mathrm{~cm}$ & Diploid & $>75$ \\
\hline \multicolumn{7}{|c|}{ Epithelial-Myoepithelial Carcinoma } \\
\hline \#13 & 84 & M & Parotid & $\leq 4 \mathrm{~cm}$ & Aneuploid & $50-75$ \\
\hline \#14 & 71 & M & Parotid & $\leq 4 \mathrm{~cm}$ & Diploid & $>75$ \\
\hline$\# 15$ & 72 & $\mathrm{~F}$ & Parotid & $\leq 4 \mathrm{~cm}$ & Aneuploid & $>75$ \\
\hline \#16 & 31 & $\mathrm{~F}$ & Palate & $\leq 4 \mathrm{~cm}$ & Diploid & $>75$ \\
\hline \multicolumn{7}{|l|}{ Mucoepidermoid Carcinoma } \\
\hline \multicolumn{7}{|l|}{ High grade } \\
\hline$\# 17$ & 29 & M & Palate & $\leq 4 \mathrm{~cm}$ & Diploid & $>75$ \\
\hline$\# 18$ & 41 & $\mathrm{~F}$ & Palate & $\leq 4 \mathrm{~cm}$ & Diploid & $>75$ \\
\hline \#19 & 54 & M & $\begin{array}{l}\text { Minor gland } \\
\text { floor mouth }\end{array}$ & $\leq 4 \mathrm{~cm}$ & Aneuploid & $>75$ \\
\hline$\# 20$ & 75 & M & Retromolar & $\leq 4 \mathrm{~cm}$ & Aneuploid & $>75$ \\
\hline \multicolumn{7}{|l|}{ Intermediate grade } \\
\hline$\# 21$ & 19 & $\mathrm{~F}$ & Parotid & $\leq 4 \mathrm{~cm}$ & Diploid & $>75$ \\
\hline$\# 22$ & 23 & $\mathrm{~F}$ & Parotid & $\leq 4 \mathrm{~cm}$ & Diploid & $>75$ \\
\hline \multicolumn{7}{|l|}{$\begin{array}{l}\text { Carcinoma ex- } \\
\text { pleomorphic adenoma }\end{array}$} \\
\hline$\# 23$ & 27 & M & Parotid & $\leq 4 \mathrm{~cm}$ & Diploid & $>75$ \\
\hline$\# 24$ & 45 & M & Parotid & $>4 \mathrm{~cm}$ & Aneuploid & $>75$ \\
\hline$\# 25$ & 78 & $\mathrm{~F}$ & Parotid & $>4 \mathrm{~cm}$ & Aneuploid & $>75$ \\
\hline \#26 & 42 & M & Parotid & $>4 \mathrm{~cm}$ & Aneuploid & $>75$ \\
\hline$\# 27$ & 69 & M & Parotid & $\leq 4 \mathrm{~cm}$ & Diploid & $>75$ \\
\hline \#28 & 87 & $\mathrm{~F}$ & Parotid & $\leq 4 \mathrm{~cm}$ & Diploid & $>75$ \\
\hline
\end{tabular}

M: male; F: female. 
very low mutation rate and currently 157 mutations were described in the COSMIC database, the vast majority being either missense or synonymous mutations (In: http://cancer. sanger.ac.uk/cosmic/gene/analysis? In=USP44\#dist). In addition, the antibody used in this study is polyclonal and the subcellular location may vary according to the focused tissue (2). Suresh et al. identified different results when producing antibodies with varying lengths (225-630 and 178-190 amino acids) (2). The status of cell cycle may also be associated with different patterns of USP44 expression, as observed by Zhang et al. (16). They reported high levels of USP44 expression during interphase and lower levels in mitosis phase (16). In addition to the above mentioned, tumor heterogeneity may also account for the lack of association of USP44 expression with ploidy, as different group of cells were used in each assay.

Tumor cell DNA ploidy has been linked to behavior of different types of neoplasms, including salivary gland tumors $(7,14,15)$. In agreement to reported by others $(7,15)$, in this subset of investigated malignant tumors was identified varying DNA content among different tumor types, with high percentage of PLGA cases $(71,5 \%)$ and all ACCs were diploid (8). However, the ploidy was not correlated to extension of the lesions.

USP44 overexpression has been described in T-cell acute lymphoblastic leukaemia and it was associated with the aneuploidy involved in the pathogenesis of this disease (16). Conversely, low levels of USP44 have been described in some human cancers including B-cell acute lymphoblastic leukemia, glioblastoma, breast, colorectal, esophageal, kidney and testicular cancer (16). In lung adenocarcinomas, USP44 mRNA expression levels are reduced and correlate with poor prognosis (5). It has recently been shown that USP44 is inactivated by hypermethylation in colorectal adenomas, but such epigenetic inactivation is not associated with aneuploidy in colorectal neoplasia (17). This last finding is in line with the study results. Although in this study some ACC samples showed a reduced immunoexpression of USP44 compared to the other malignant tumor groups (i.e. PLGA, EMC, MEC, Caex-PA), it was concluded that USP44 expression seems not to influence the DNA ploidy status in the subset of the investigated tumors.

\section{Resumo}

Instabilidade cromossômica acarretando aneuploidia é um dos fatores marcantes de neoplasias malignas humanas. USP44 (peptidase especifica de ubiquitina 44) é uma importante molécula que exerce um papel regulador no ciclo celular e sua perda pode acarretar em segregação cromossômica deficiente, aneuploidia e desenvolvimento de tumores in vivo. Neste estudo, investigou-se a expressão imuno-histoquímica da proteína USP44 em 28 neoplasias malignas de glândulas salivares, associando-se os resultados com o estado de ploidia do DNA avaliado por citometria de fluxo. A proteina USP44 apresentou ampla expressão na maioria das amostras avaliadas e não foi observada associação entre a expressão protéica e o estado de ploidia do DNA ou extensão do tumor. Baseando-se nos resultados, concluiu-se que a aneuploidia das neoplasias malignas de glândulas de salivares incluidas neste estudo não foi influenciada pela perda de expressão da proteina USP44.

\section{Acknowledgements}

This work was supported in part by National Council for Scientific and Technological Development (CNPq)/Brazil and Fundação de Amparo à Pesquisa do Estado de Minas Gerais (FAPEMIG)/Brazil. Gomez R.S. and Gomes C.C. are research fellows at CNPq. We are grateful to the PróReitoria de Pesquisa da Universidade Federal de Minas Gerais for funding.

\section{References}

1. Quesada V, Diaz-Perales A, Gutiérrez-Fernández A, Garabaya C, Cal S, López-Otín C. Cloning and enzymatic analysis of 22 novel human ubiquitin-specific proteases. Biochem Biophys Res Commun 2004;314:54-62.

2. Suresh B, Ramakrishna S, Lee HJ, Choi JH, Kim JY, Ahn WS, et al.. K48and K63-linked polyubiquitination of deubiquitinating enzyme USP44. Cell Biol Int 2010;34:799-808.

3. Stegmeier F, Rape M, Draviam VM, Nalepa G, Sowa ME, Ang XL, et al.. Anaphase initiation is regulated by antagonistic ubiquitination and deubiquitination activities. Nature 2007;446:876-881.

4. Song EJ, Werner SL, Neubauer J, Stegmeier F, Aspden J, Rio D, et al.. The Prp19 complex and the Usp4Sart3 deubiquitinating enzyme control reversible ubiquitination at the spliceosome. Genes Dev 2010;24:14341447.

5. Zhang Y, Foreman O, Wigle DA, Kosari F, Vasmatzis G, Salisbury JL, et al.. USP44 regulates centrosome positioning to prevent aneuploidy and suppress tumorigenesis. J Clin Invest 2012;122:4362-4374.

6. Driemel 0 , Maier H, Kraft K, Haase $\mathrm{S}$, Hemmer J: Flow cytometric DNA ploidy in salivary gland tumours. Oncol Rep 2005;13:161-165.

7. Vargas PA, Torres-Rendon A, Speight PM. DNA ploidy analysis in salivary gland tumours by image cytometry. J Oral Pathol Med 2007;36:371-376.

8. Gomes CC, Diniz MG, Oliveira CS, Tavassoli M, Odell EW, Gomez RS, et al.. Impact of WWOX alterations on $\mathrm{p} 73, \Delta \mathrm{Np} 73, \mathrm{p} 53$, cell proliferation and DNA ploidy in salivary gland neoplasms. Oral Dis 2011;17:564-571.

9. Driemel 0, Kraft K, Hemmer J. Flow cytometric S-phase fraction contributes to diagnosis of diploid malignant salivary gland tumours. Int J Oral Maxillofac Surg 2006;35:947-950.

10. Gomes CC, Bernardes VF, Odell EW, Gomez RS. STAG2 loss of expression is rare in aneuploid malignant salivary gland neoplasms. J Oral Pathol Med 2014;43:273-275.

11. Speight PM, Barrett AW. Salivary gland tumours. Oral Dis 2002;8:229240.

12. Walker RA. Quantification of immunohistochemistry issues concerning methods, utility and semiquantitative assessment I. Histopathology 2006;49:406-410.

13. Holland AJ, Cleveland DW. The deubiquitinase USP44 is a tumor suppressor that protects against chromosome missegregation. J Clin Invest 2012;122:4325-4328.

14. Enamorado I, Lakhani $R$, Korkmaz $H$, Yoo GH, Del Mar Alonso M, Pietraszkiewicz $\mathrm{H}$, et al.. Correlation of histopathological variants, cellular DNA content and clinical outcome in adenoid cystic carcinoma of the salivary glands. Otolaryngol Head Neck Surg 2004;131:646-650.

15. Monteiro LS, Palmeira C, Bento MJ, Lopes C. DNA content in malignant salivary gland tumours. Oral Dis 2009;15:295-301.

16. Zhang Y, van Deursen J, Galardy PJ. Overexpression of ubiquitin specific protease 44 (USP44) induces chromosomal instability and is frequently observed in human T-cell leukemia. PLoS One 2011;6:e23389.

17. Sloane MA, Wong JW, Perera D, Nunez AC, Pimanda JE, Hawkins NJ, et al.. Epigenetic inactivation of the candidate tumor suppressor USP44 is a frequent and early event in colorectal neoplasia. Epigenetics 2014;9:1092-1100. 